\title{
Hubungan Kadar Gula Darah dan Hematokrit dengan Luaran Pasien Cedera Otak Traumatik Berdasarkan Skor GCS di RSUD Ulin Banjarmasin
}

\author{
Rasyid Riddo*), Kenanga M. Sikumbang $^{* *}$, Asnawati***) $^{* *}$ \\ ${ }^{*}$ Fakultas Kedokteran, Universitas Lambung Mangkurat Banjarmasin, ${ }^{* *}$ Departemen Anestesiologi dan Terapi \\ Intensif, Fakultas Kedokteran, Universitas Lambung Mangkurat/RSUD Ulin Banjarmasin, ${ }^{* * *}$ Departemen \\ Biomedik, Fakultas Kedokteran, Universitas Lambung Mangkurat Banjarmasin
}

\begin{abstract}
Abstrak
Latar Belakang dan Tujuan: Tingkat keparahan dari cedera otak traumatik (COT) dapat dinilai menggunakan Glasgow Coma Scale (GCS). Saat terjadi COT, tubuh mengeluarkan hormon sebagai respons stres fase akut sehingga terjadi peningkatan kadar gula darah reaktif. Selain itu juga memengaruhi pembuluh dan komponen darah sehingga akan memengaruhi hematokrit. Tujuan penelitian ini untuk mengetahui apakah terdapat hubungan antara kadar gula darah dan hematokrit dengan luaran pasien COT berdasarkan skor GCS di RSUD Ulin Banjarmasin.

Subjek dan Metode: Penelitian ini bersifat observasional analitik dengan pendekatan cross-sectional. Data diambil secara prospektif dengan metode consecutive sampling. Data yang terkumpul dianalisis hasilnya menggunakan uji korelasi non-parametrik Spearman.

Hasil: Sebanyak 45 sampel didapat secara consecutive sampling. Pada hari ke-7, 40 pasien memiliki luaran baik dan 5 pasien memiliki luaran buruk. Analisis menggunakan uji korelasi Spearman menunjukkan terdapat hubungan kadar gula darah dengan luaran pasien COT $(\mathrm{p}=0,044 ; \mathrm{r}=0,302)$ tetapi tidak terdapat hubungan antara hematokrit dengan luaran $(\mathrm{p}=0,958)$.

Simpulan: Terdapat hubungan kadar gula darah dengan luaran pasien COT, tetapi tidak terdapat hubungan hematokrit dengan luaran pasien COT berdasarkan skor GCS.
\end{abstract}

Kata kunci: cedera otak traumatik, kadar gula darah, hematokrit, skor GCS

JNI 2021; 10 (2): 71-9

\section{Association of Blood Sugar Levels and Hematocrit with TBI Patient Outcome Based on GCS Score at Ulin General Hospital Banjarmasin}

\begin{abstract}
Background and Objective: Glasgow coma scale (GCS) examination is done to categorize the severity and determine the outcome in TBI. When TBI occurs, the body release hormones in the acute phase of stress response which will occur an increase blood sugar levels. It will also affect hematocrit. The purpose of this study was analyze correlation between blood sugar levels and hematocrit with TBI patients outcome based on GCS score in Ulin General Hospital Banjarmasin.

Subject and Method: The design of this study was observational analytic with cross-sectional approach. Data acquired prospectively with consecutive sampling method. The collected data will be analyzed using the Spearman non-parametric trial.

Result: Total of 45 samples were obtained by consecutive sampling. On day 7, 40 patients had good outcomes and 5 patients had poor outcomes. Analysis using the Spearman correlation test showed association between blood sugar levels and TBI patients outcome $(\mathrm{p}=0,044 ; \mathrm{r}=0,302)$ but no association between hematocit and TBI patients outcome $(p=0,958)$.

Conclusion: It was concluded that there is an association between blood sugar levels and TBI patients outcome, but there is no association between hematocrit and TBI patients outcome based on GCS score.
\end{abstract}

Key words: traumatic brain injury, sugar blood levels, hematocrit, GCS score

JNI 2021; 10 (2): 71-9 


\section{Pendahuluan}

Cedera otak traumatik (COT) merupakan jenis trauma yang angka kejadiannya paling tinggi dan penyebab utama kematian serta kecacatan. Data dari Centers for Disease Control and Prevention menunjukkan lebih dari 1,7 juta orang di Amerika Serikat mengalami COT setiap tahunnya dan sekitar 275 ribu orang menjalani perawatan serta terdapat lebih dari 50 ribu kasus kematian. Cedera otak traumatik ringan merupakan kasus terbanyak dan $8-10 \%$ sisanya merupakan cedera sedang dan berat. ${ }^{1}$ Di Indonesia, angka kejadian COT masih cukup tinggi dan terus meningkat setiap tahunnya.

Hasil Riskesdas tahun 2013 menunjukkan insidens COT dengan case fatality rate sebanyak 100.000 jiwa meninggal dunia. Laporan tahunan dari Instalasi Gawat Darurat (IGD) RSUD Ulin Banjarmasin tahun 2014, menuliskan bahwa COT termasuk ke dalam 10 besar kasus bedah terbanyak yaitu sebesar 1.187 kasus dari 4.406 kasus. Sebanyak $64,6 \%$ mengalami cedera yang bersifat ringan, kemudian $16,7 \%$ mengalami cedera sedang, dan sisanya $18,7 \%$ mengalami cedera otak traumatik yang bersifat berat. $^{2}$ Angka kejadian COT pada laki-laki tiga kali dari angka kejadian pada perempuan. Cedera otak traumatik banyak terjadi pada usia dewasa muda dibawah 45 tahun dan anak-anak usia 1-15 tahun dengan penyebab utama adalah kecelakaan lalu lintas dan terjatuh dari ketinggian. Selama 20 tahun terakhir penatalaksanaan pasien dengan COT telah meningkat secara bermakna dan pedoman penatalaksanaan berbasis bukti telah dikembangkan. ${ }^{3}$

Pada pasien COT seringkali mengalami peningkatan kadar gula darah. Peningkatan kadar gula darah sebagai suatu komponen respons stres pada fase akut, hampir selalu ada pada cedera otak berat. Pada fase akut, tubuh akan beradaptasi terhadap stres dan akan merangsang terjadinya peningkatan sekresi hormon (growth hormone, catecholamine) dan perangsangan sistem corticotropin releasing hormone. Perangsangan hormon-hormon tersebut yang dapat mengakibatkan peningkatan kadar gula darah. ${ }^{4}$ Peningkatan kadar gula darah dapat digunakan untuk memprediksi tingkat keparahan pasien yang mengalami cedera otak traumatik. Peningkatan kadar gula darah akan memacu terjadinya cedera sekunder yang selanjutnya menyebabkan kerusakan pada sel. Hal tersebut dapat memperburuk kerusakan neurologik yang akhirnya dapat mengakibatkan prognosis yang lebih buruk lagi. ${ }^{5}$

Pasien COT dengan kadar gula darah puncak 24 jam kurang dari atau sama dengan $200 \mathrm{mg} /$ dl memiliki luaran yang lebih baik pada hari ke-18, setelah 3 bulan, dan 1 tahun dibandingkan pasien COT dengan kadar gula darah puncak 24 jam lebih dari $200 \mathrm{mg} / \mathrm{dl} .^{5}$ Peningkatan kadar gula darah juga dapat meningkatkan nilai hematokrityang menyebabkan viskositas darah menjadi meningkat. ${ }^{6}$ Kadar gula darah yang tinggi akan meningkatkan osmolaritas darah dan permeabilitas kapiler sehingga akan terjadi kebocoran plasma dan peningkatan hematokrit darah. Selain itu kadar gula darah yang tinggi juga menyebabkan diuresis osmotik yang juga mempengaruhi volume plasma. Apabila viskositas darah meningkat, maka perfusi darah ke organ-organ vital akan menurun, termasuk ke otak. ${ }^{7}$ Hematokrit darah pasien COT memiliki rerata tidak kurang dari $30 \%$ pada saat diukur pertama kali. Kadar yang rendah akan menurunkan suplai oksigen ke otak sehingga sangat rentan terjadi hipoksia, terlebih pada pasien COT dan kadar yang tinggi akan memperlambat aliran darah menuju otak. Hematokrit darah sekitar 30-35\% diyakini sebagai kadar optimal pada penderita cedera otak traumatik agar dapat mempertahankan aliran darah otak dengan normal. ${ }^{8}$

Berdasarkan latar belakang di atas diketahui bahwa kadar gula darah yang tinggi akan meningkatkan morbiditas dan mortalitas pasien dan nilai hematokrit yang tinggi akan menyebabkan viskositas darah meningkat yang akan mengganggu aliran darah ke otak. Penelitian ini belum pernah dilakukan di RSUD Ulin Banjarmasin sehingga ingin diketahui bagaimana hubungan kadar gula darah dan hematokrit dengan luaran pasien COT berdasarkan skor GCS di RSUD Ulin Banjarmasin. 


\section{Subjek dan Metode}

Rancangan penelitian ini adalah observasional analitik dengan pendekatan cross-sectional untuk pengukuran kadar gula darah dan hematokrit serta penilaian berulang skor untuk GCS. Sampel penelitian adalah 45 pasien yang telah memenuhi kriteria inklusi dan telah menandatangani lembar informed consent dari peneliti. Kriteria inklusi sampel penelitian ini adalah: a). Pasien yang berusia antara 18-60 tahun; b). Pasien COT tunggal (tidak ada trauma berat pada bagian tubuh lain); c). Pasien atau keluarga pasien bersedia ikut serta dalam penelitian. Kriteria eksklusi sampel penelitian ini adalah: a). Pasien COT dengan riwayat diabetes mellitus yang diketahui dengan anamnesis langsung atau alloanamnesis; b). Pasien COT dalam keadaan hamil.

Peneliti akan melakukan observasi dengan cara menilai skor GCS setelah pasien stabil untuk menentukan tingkat keparahan COT yang dikategorikan menjadi COT ringan (13-15), COT sedang (9-12), dan COT berat (3-8) pada saat pasien datang ke IGD RSUD Ulin Banjarmasin, selanjutnya pasien akan dilakukan pengambilan darah untuk pemeriksaan kadar gula darah dan hematokrit. Setelah 7 hari masuk rumah sakit, dilakukan pemeriksaan ulang skor GCS pasien. Dikatakan membaik apabila skor GCS pasien meningkat atau tetap dari GCS awal dan dikatakan memburuk apabila terjadi penurunan skor GCS dari skor GCS awal atau meninggal. Data yang terkumpul akan ditabulasi dan dianalisis hasilnya menggunakan software SPSS versi 23 dengan uji komparasi Kolmogorov-Smirnov, Chi Square, Kruskal Wallis dan One Way Anova serta uji korelasi non-parametrik Spearman.

\section{Hasil}

Telah dilakukan penelitian mengenai hubungan kadar gula darah dan hematokrit dengan luaran pasien cedera otak traumatik berdasarkan skor GCS di RSUD Ulin Banjarmasin pada bulan JuliOktober 2019. Populasi pasien COT berjumlah 70 pasien tetapi hanya 45 pasien yang memenuhi kriteria inklusi penelitian. Karakteristik data peneltian ini dapat dilihat pada tabel 1 .
Tabel 1. Distribusi Karakteristik Umum Subjek Penelitian Hubungan Kadar Gula Darah dan Hematokrit dengan Luaran Pasien COT Berdasarkan Skor GCS di RSUD Ulin Banjarmasin

\begin{tabular}{|c|c|c|}
\hline Karakteristik & Jumlah (\%) & Nilai $p$ \\
\hline \multicolumn{3}{|l|}{ Distribusi } \\
\hline \multicolumn{3}{|l|}{$\mathrm{COT}^{\mathrm{a}}$} \\
\hline Ringan & $21(46,67 \%)$ & \multirow{3}{*}{0,026} \\
\hline Sedang & $16(35,56 \%)$ & \\
\hline Berat & $8(17,78 \%)$ & \\
\hline \multicolumn{3}{|l|}{ Usia (tahun) } \\
\hline $18-40$ & $33(73,33 \%)$ & \multirow[t]{2}{*}{0,109} \\
\hline $41-60$ & $12(26,67 \%)$ & \\
\hline \multicolumn{3}{|l|}{ Jenis Kelamin } \\
\hline Laki-laki & $31(68,89 \%)$ & \multirow[t]{2}{*}{1,000} \\
\hline Perempuan & $14(31,11 \%)$ & \\
\hline \multicolumn{3}{|l|}{ Mekanisme $^{\mathrm{b}}$} \\
\hline KLL & $42(93,33 \%)$ & \multirow[t]{2}{*}{1,000} \\
\hline Non KLL & $3(6,67 \%)$ & \\
\hline \multicolumn{3}{|l|}{ Terapi } \\
\hline Konservatif & $34(75,56 \%)$ & \multirow[t]{2}{*}{1,000} \\
\hline Operatif & $11(24,44 \%)$ & \\
\hline \multicolumn{3}{|c|}{$\begin{array}{l}\text { Keterangan: } \\
\text { COT: Cedera Otak Traumatik; KLL: Kecelakaan Lalu Lin- } \\
\text { tas. } \\
\text { Nilai p: menggunakan uji statistik Kolmogorov-Smirnov } \\
\text { dan Chi Square. } \\
\text { aDiklasifikasikan berdasarkan skor GCS saat pertama kali } \\
\text { masuk rumah sakit. } \\
\text { bMekanisme trauma yang menyebabkan terjadinya cedera } \\
\text { otak traumatik. }\end{array}$} \\
\hline
\end{tabular}

Berdasarkan tabel 1 pasien cedera otak traumatik di RSUD Ulin Banjarmasin dalam periode Juli sampai Oktober 2019 didapatkan sebanyak 45 pasien dengan distribusi kejadian tertinggi yaitu COT ringan, kemudian diikuti dengan COT sedang dan COT berat. Tingkat keparahan COT berhubungan dengan luaran pasien COT pada hari ke-7 dengan nilai $\mathrm{p}=0,026$. Penelitian ini membagi usia pasien menjadi dua kategori yaitu usia 18-40 tahun (dewasa muda) dan usia 41-60 tahun (dewasa lanjut). Hasil penelitian ini menunjukkan bahwa pasien COT didominasi oleh pasien berusia dewasa muda $(71,74 \%)$ dibandingkan usia dewasa lanjut $(28,26 \%)$. Berdasarkan jenis kelamin penelitian ini menunjukkan kejadian COT lebih banyak 
terjadi pada laki-laki $(69,57 \%)$ dibandingkan dengan perempuan (30,43\%). Mekanisme cedera pada penelitian ini menunjukkan bahwa kecelakaan lalu lintas merupakan mekanisme terbanyak terjadinya COT $(93,48 \%)$. Untuk terapi pasien COT di RSUD Ulin Banjarmasin periode Juli sampai Oktober 2019, sebesar 76,09\% untuk terapi konservatif dan $23,91 \%$ untuk tindakan operatif.

Berdasarkan tabel 2 didapatkan pada penelitian ini untuk kadar gula darah pasien COT dengan rerata tertinggi ada pada pasien COT berat diikuti COT sedang dan ringan. Terdapat perbedaan yang bermakna antar tingkat keparahan.

Tabel 2. Distribusi Kadar Gula Darah Subjek Penelitian

\begin{tabular}{lll}
\hline COT & Rerata \pm SD $(\mathrm{mg} / \mathrm{dL})$ & Nilai $\mathrm{p}$ \\
\hline Ringan & $118,5 \pm 25,65$ & \\
Sedang & $137,25 \pm 29,33$ & 0,005 \\
Berat & $161,13 \pm 43,14$ & \\
\hline
\end{tabular}

Nilai P: Berdasarkan uji statistik Kruskal Wallis

Berdasarkan tabel 3 nilai hematokrit pasien COT ringan, sedang dan berat memiliki rerata yang hampir sama dan tidak terdapat perbedaan yang signifikan antara pasien dengan COT ringan, sedang dan berat.

Tabel 3. Distribusi Hematokrit Subjek Penelitian

\begin{tabular}{lll}
\hline COT & Rerata \pm SD $(\%)$ & Nilai $p$ \\
\hline Ringan & $41,5 \pm 3,33$ & \\
Sedang & $38,71 \pm 5,48$ & 0,129 \\
Berat & $41,5 \pm 4,66$ & \\
\hline
\end{tabular}

Nilai P: Berdasarkan uji statistik One Way Anova

Dari hasil penelitian pada tabel 4 luaran pasien COT dibagi menjadi baik dan buruk berdasarkan skor GCS. Dari 21 pasien COT ringan, sejumlah 21 pasien $(100 \%)$ memiliki luaran baik pada hari ke-7 pasca cedera. Untuk pasien COT sedang, dari 16 pasien didapatkan 15 pasien $(93,75 \%)$ memiliki luaran baik pada hari ke-7 pasca cedera dan 1 pasien $(6,25 \%)$ memiliki luaran buruk. Sedangkan untuk pasien COT berat, dari 8 pasien sejumlah 4 pasien $(50 \%)$ memiliki luaran baik dan 4 pasien $(50 \%)$ memiliki luaran buruk.
Tabel 4. Luaran pada Hari ke-7 Subjek Penelitian

\begin{tabular}{lllll}
\hline $\begin{array}{l}\text { GCS } \\
\text { Hari ke-0 }\end{array}$ & $\begin{array}{l}\text { Jumlah } \\
(\mathrm{n})\end{array}$ & $\begin{array}{l}\text { Luaran } \\
\text { pada } \\
\text { Hari } \\
\text { ke-7a }\end{array}$ & $\begin{array}{l}\text { Jumlah } \\
(\mathrm{n})\end{array}$ & $\begin{array}{l}\text { Persentase } \\
(\%)\end{array}$ \\
\hline $\begin{array}{l}\text { COT } \\
\text { Ringan }\end{array}$ & 21 & Baik & 21 & $100 \%$ \\
& & Buruk & 0 & $0 \%$ \\
COT & 16 & Baik & 15 & $93,75 \%$ \\
Sedang & & & & \\
COT & 8 & Baik & 4 & $50 \%$ \\
Berat & & & & $50 \%$ \\
& & Buruk & 4 & $50 \%$ \\
\hline
\end{tabular}

Keterangan:

abik apabila pasien mengalami peningkatan skor GCS pada hari ke-7 atau tetap; buruk apabila pasien mengalami penurunan skor GCS pada hari ke-7 atau meninggal

Tabel 5. Hubungan Kadar Gula Darah dengan Luaran Pasien COT Berdasarkan Skor GCS di RSUD Ulin Banjarmasin

\begin{tabular}{lllll}
\hline $\begin{array}{l}\text { Luaran } \\
\text { Pasien Hari } \\
\text { ke-7 }\end{array}$ & $\mathrm{n}$ & $\begin{array}{l}\text { Kadar Gula } \\
\text { Darah }\end{array}$ & $\mathrm{p}$ & $\mathrm{r}$ \\
\hline Baik & 40 & $129,6 \pm 29,78$ & 0,044 & 0,302 \\
Buruk & 5 & $157,8 \pm 54,75$ & & \\
\hline
\end{tabular}

Keterangan:

Data disajikan dalam bentuk numerik untuk variabel bebas dan ordinal untuk variabel terikat. Uji statistik bivariat menggunakan uji korelasi non-parametrik Spearman. Bermakna jika nilai $\mathrm{p} \leq 0,05$

$\mathrm{p}=$ signifikansi

$\mathrm{r}=$ koefisien korelasi

Uji statistik bivariat dengan uji korelasi nonparametrik Spearman (tabel 5) diperoleh nilai $\mathrm{p}=0,044$. Dengan demikian nilai $\mathrm{p}$ bermakna karena $\leq 0,05$ sehingga hipotesis yang diajukan dapat diterima bahwa terdapat hubungan antara kadar gula darah dengan luaran pasien COT berdasarkan skor GCS di RSUD Ulin Banjarmasin. Untuk korelasi koefisien yang didapatkan adalah sebesar 0,302 yang berarti kekuatan hubungan adalah cukup. Berdasarkan tabel 5 didapatkan bahwa semakin tinggi kadar gula darah pasien COT pada hari ke-0 
maka kemungkinan luaran buruk pada hari ke-7 semakin meningkat, tetapi kadar gula darah tidak dapat dijadikan prediktor luaran secara independen karena kekuatan korelasi hanya sebatas cukup.

Berdasarkan tabel 6 setelah dilakukan uji statistik dengan uji korelasi non-parametrik Spearman diperoleh nilai $\mathrm{p}=0,958$ untuk hubungan variabel hematokrit dengan luaran pasien COT berdasarkan skor GCS. Dengan demikian nilai $\mathrm{p}$ tidak bermakna karena $>0,05$ sehingga dapat disimpulkan hipotesis yang diajukan ditolak. Menurut penelitian ini tidak terdapat hubungan antara hematokrit dengan luaran pasien COT berdasarkan skor GCS di RSUD Ulin Banjarmasin, sehingga hematokrit tidak bisa digunakan sebagai prediktor luaran pasien COT.

Tabel 6. Hubungan Hematokrit dengan Luaran Pasien COT Berdasarkan Skor GCS di RSUD Ulin Banjarmasin

\begin{tabular}{lllll}
\hline $\begin{array}{l}\text { Luran } \\
\text { Pasien Hari } \\
\text { ke-7 }\end{array}$ & $\mathrm{n}$ & Hematokrit & $\mathrm{p}$ & $\mathrm{r}$ \\
\hline Baik & 40 & $39,75 \pm 5,06$ & & \\
Buruk & 5 & $40,46 \pm 2,39$ & 0,958 & 0,008 \\
\hline
\end{tabular}

Keterangan:

Data disajikan dalam bentuk numerik untuk variabel bebas dan ordinal untuk variabel terikat. Uji statistik bivariat menggunakan uji korelasi non-parametrik Spearman. Bermakna jika nilai $\mathrm{p} \leq 0,05$

$\mathrm{p}=$ signifikansi

$\mathrm{r}=$ koefisien korelasi

\section{Pembahasan}

Pada hasil penelitian ini didapatkan sebanyak 45 pasien dengan distribusi kejadian tertinggi yaitu COT ringan, kemudian diikuti dengan COT sedang dan COT berat. Persentase ini sebanding dengan penelitian lain yang menyatakan bahwa pasien COT di RSUP Haji Adam Malik Medan periode Oktober 2016 sampai Maret 2017 terdiri dari 203 pasien dengan COT ringan (78,7\%), 43 pasien COT sedang (16,3\%), dan 13 pasien COT berat (5\%). ${ }^{9}$ Pasien COT berat lebih sedikit dibandingkan dengan pasien COT ringan atau sedang dikarenakan banyaknya pasien COT berat mengalami kematian di tempat kejadian sebelum sempat ditransportasikan ke rumah sakit. Selain itu juga pasien COT berat tiba di rumah sakit dengan kondisi yang sudah sangat buruk, sehingga banyak pasien yang meninggal sebelum atau saat dilakukan tindakan resusitasi dan belum sempat dilakukan pemeriksaan laboratorium. ${ }^{9}$ Tingkat keparahan COT berhubungan dengan luaran pasien COT pada hari ke-7 dengan nilai $\mathrm{p}=0,026$.

Hasil penelitian ini menunjukkan bahwa pasien COT didominasi oleh pasien berusia dewasa muda $(71,74 \%)$ dibandingkan usia dewasa lanjut (28,26\%). Penelitian ini sebanding dengan penelitian lain yang dilakukan di RSUP Prof. Dr. R.D Kandou Manado bahwa dalam periode September 2015 sampai Agustus 2016 didapatkan 26 pasien (65\%) berusia 18-40 tahun dan 14 pasien (35\%) berusia 41-60 tahun. ${ }^{10}$ Tingginya angka kejadian COT pada kelompok usia produktif dapat dikaitkan dengan tingginya tingkat mobilitas dan perkembangan kejiwaan, karena usia dewasa muda perkembangan jiwanya masih belum stabil sehingga belum dapat mengendalikan emosi dirinya sendiri. Keadaan ini yang menyebabkan sikap kurang waspada sehingga sering kurang memperhatikan keselamatan dirinya sendiri maupun orang lain. ${ }^{10}$

Kejadian COT lebih banyak terjadi pada lakilaki $(69,57 \%)$ dibandingkan dengan perempuan $(30,43 \%)$. Hasil ini sebanding dengan penelitian lain yang dilakukan di RSUP Haji Adam Malik Medan bahwa dari 258 pasien COT pariode Oktober 2016 sampai Maret 2017 didapatkan 198 pasien $(76,7 \%)$ dengan jenis kelamin lakilaki dan 60 pasien $(23,3 \%)$ dengan jenis kelamin perempuan. ${ }^{9}$ Penelitian lain juga menyebutkan laki-laki memiliki risiko lebih tinggi mengalami cedera otak traumatik dibandingkan perempuan karena faktor pekerjaan yang lebih berat. Pengendara motor laki-laki memiliki risiko kecelakaan dua kali lipat dibandingkan dengan perempuan. Faktor lain seperti aktivitas laki-laki yang cenderung berada di luar rumah juga bisa menjadifaktorrisikoterjadinyaCOT. ${ }^{11}$ Mekanisme cedera pada penelitian ini menunjukkan bahwa 
kecelakaan lalu lintas merupakan mekanisme terbanyak terjadinya COT $(93,48 \%)$. Hal ini sebanding dengan penelitian yang lain di Rumah Sakit Sentral Kamuzu Malawi periode Oktober 2016 sampai Mei 2017 bahwa 60,7\% penyebab terjadinya COT akibat kecelakaan lalu lintas. Kecelakaan lalu lintas terjadi karena keegoisan manusia seperti memotong jalan kendaraan tanpa haluan, memacu kecepatan kendaraan tanpa kendali, melanggar rambu-rambu lalu lintas, serta kurangnya kesadaran menggunakan alat pelindung diri seperti helm. ${ }^{12}$ Terapi pasien COT di RSUD Ulin Banjarmasin periode Juli sampai Oktober 2019 sebesar 76,09\% untuk terapi konservatif dan $23,91 \%$ untuk tindakan operatif. Penelitian di RSUD Ulin sebelumnya juga didapatkan terapi konservatif lebih banyak dibandingkan dengan terapi operatif. Dari 48 pasien COT periode Juli sampai September 2018 di RSUD Ulin Banjarmasin sebanyak 70,8\% diberikan terapi konservatif dan 29,2\% dilakukan tindakan operatif. ${ }^{13}$ Peneliti lain menyatakan bahwa terapi COT sangat bergantung pada proses patofisiologinya. Terapi konservatif seperti memberikan oksigen hiperbarik sering digunakan karena dapat memperbaiki gejala dan luaran pasien. $^{14}$

Berdasarkan tabel 2 terdapat perbedaan yang bermakna antar tingkat keparahan. Hasil penelitian tersebut sesuai dengan penelitian sebelumnya yang dilakukan di RSUD Ulin Banjarmasin menyatakan bahwa dari 33 pasien COT ringan sebesar 73\% memiliki kadar GDS normal, 13 pasien COT sedang (69\%) mengalami peningkatan kadar GDS ringan dan untuk 11 pasien COT berat (64\%) mengalami peningkatan kadar GDS sedang. ${ }^{15}$ Namun data pada penelitian ini tidak sesuai dengan penelitian yang dilakukan penelitian lain yang dilakukan di RS Dr. Kariadi Semarang pada tahun 2007, dari 52 pasien COT sedang dan berat didapatkan rerata kadar GDS normal $(122,7 \mathrm{mg} / \mathrm{dL})$. Hal ini bisa terjadi karena penelitian menganalisis semua pasien COT termasuk dengan berbagai kelainan di CT scan, selain itu juga pasien yang meninggal selama perawatan tetap diikutsertakan. ${ }^{16}$

Berdasarkan tabel 3 tidak terdapat perbedaan yang signifikan antara pasien dengan COT ringan, sedang dan berat. Data tersebut sebanding dengan penelitian lain pada tahun 2013 di RSUP Haji Adam Malik Medan bahwa dari 49 pasien COT, sebanyak 49 pasien (100\%) mengalami penurunan nilai hematokrit. ${ }^{17}$ Namun, hasil ini tidak sejalan dengan penelitian sebelumnya pada tahun 1984 yang menyatakan pasien COT berat memiliki nilai hematokrit yang lebih tinggi dibandingkan COT ringan maupun sedang. ${ }^{18}$

Dari hasil penelitian pada tabel 4 luaran pasien COT dibagi menjadi baik dan buruk berdasarkan skor GCS. Dari 21 pasien COT ringan, sejumlah 21 pasien $(100 \%)$ memiliki luaran baik pada hari ke-7 pasca cedera. Untuk pasien COT sedang, dari 16 pasien didapatkan 15 pasien $(93,75 \%)$ memiliki luaran baik pada hari ke-7 pasca cedera dan 1 pasien $(6,25 \%)$ memiliki luaran buruk. Sedangkan untuk pasien COT berat, dari 8 pasien sejumlah 4 pasien $(50 \%)$ memiliki luaran baik dan 4 pasien $(50 \%)$ memiliki luaran buruk. Hasil ini sebanding dengan penelitian lain pada tahun 2011 di IGD RSU Tugurejo Semarang bahwa dari 57 pasien COT 19 pasien (33,3\%) meninggal dunia dan 38 pasien $(66,7 \%)$ hidup. ${ }^{19}$ pasien $(100 \%)$ yang meninggal dunia mengalami COT berat dengan rentang skor GCS 3 sampai 5. ${ }^{19}$

Uji statistik bivariat dengan uji korelasi nonparametrik Spearman (tabel 5) diperoleh nilai $\mathrm{p}=0,044$. Dengan demikian nilai $\mathrm{p}$ bermakna karena $\leq 0,05$ sehingga hipotesis yang diajukan dapat diterima bahwa terdapat hubungan antara kadar gula darah dengan luaran pasien COT berdasarkan skor GCS di RSUD Ulin Banjarmasin. Untuk korelasi koefisien yang didapatkan adalah sebesar 0,302 yang berarti kekuatan hubungan adalah cukup. Berdasarkan tabel 5 didapatkan bahwa semakin tinggi kadar gula darah pasien COT pada hari ke-0 maka kemungkinan luaran buruk pada hari ke-7 semakin meningkat, tetapi kadar gula darah tidak dapat dijadikan prediktor luaran secara independen karena kekuatan korelasi hanya sebatas cukup.

Penemuan ini didukung oleh hasil penelitian lain pada tahun 2017 yang menyatakan terdapat hubungan kuat antara kadar gula darah pasien COT sedang-berat dengan luaran pada hari ke- 
14 berdasarkan disability rating scale (DRS). Semakin tinggi kadar gula darah sewaktu pada hari ke-0 maka akan semakin buruk luaran pasien COT pada hari ke-14 berdasarkan DRS. ${ }^{16}$ Penelitian yang lain pada tahun 2014 juga menyebutkan terdapat hubungan antara kadar gula darah dengan luaran pasien COT. Kondisi hiperglikemia berhubungan dengan tingginya komplikasi $(p=0,019)$ dan mortalitas $(p=0,039) .{ }^{5}$ Selain itu, penemuan ini juga didukung dengan penelitian-penelitian lain yang menyebutkan semakin rendah skor GCS pasien COT maka akan semakin meningkat kadar gula darah pasien akibat hiperglikemia reaktif sebagai respon stres. Begitupun sebaliknya, pasien dengan kadar gula darah tinggi akan memperburuk luaran pasien melalui banyak mekanisme seperti asidosis laktat, ketidakseimbangan elektrolit, inflamasi, dan gangguan dari pembuluh darah. ${ }^{3,4}$

Cedera otak traumatik mempunyai banyak penyulit yang dapat menyebabkan terjadinya COT sekunder, salah satunya adalah peningkatan kadar gula darah. ${ }^{5}$ Peningkatan kadar gula darah merupakan sebuah mekanisme respons tubuh terhadap peristiwa cedera otak traumatik. ${ }^{4}$ Respon stres ini akan mengaktifkan aktivitas dari kelenjar-kelenjar untuk mesekresikan hormon yang dapat meningkatkan kadar gula darah seperti katekolamin, kortisol, glukagon dan growth hormone. Hormon katekolamin akan meningkatkan proses glikogenolisis di hepar, lipolisis pada jaringan lemak dan menurunkan sekresi insulin oleh pankreas. Hormon kortisol dan growth hormone akan meningkatkan proses glukoneogenesis yang mana dari semua proses tersebut akan meningkatkan kadar gula darah tubuh. $^{3}$ Proses glukoneogenesis sebenarnya merupakan upaya kompensasi tubuh untuk menyediakan sumber energi bagi kelangsungan metabolisme sel, karena glukosa sangat dibutuhkan sebagai bahan bakar utama bagi jaringan yang mengalami cedera. ${ }^{15}$ Namun, mekanisme peningkatan kadar gula darah pada pasien COT akan memengaruhi luaran pasien, dan cenderung meningkatkan morbiditas dan mortalitas. $^{3}$

Hiperglikemia pada trauma berhubungan erat dengen hipermetabolisme, sedangkan hipermetabolisme berkaitan erat dengan berat ringannya $\mathrm{COT}{ }^{15}$

Berdasarkan tabel 6 setelah dilakukan uji statistik dengan uji korelasi non-parametrik Spearman diperoleh nilai $\mathrm{p}=0,958$ untuk hubungan variabel hematokrit dengan luaran pasien COT berdasarkan skor GCS. Dengan demikian nilai p tidak bermakna karena $>0,05$ sehingga dapat disimpulkan hipotesis yang diajukan ditolak. Menurut penelitian ini tidak terdapat hubungan antara hematokrit dengan luaran pasien COT berdasarkan skor GCS di RSUD Ulin Banjarmasin, sehingga hematokrit tidak bisa digunakan sebagai prediktor luaran pasien COT. Hematokrit merupakan salah satu komponen penentu dari viskositas darah. Hematokrit merupakan perbandingan antara sel darah merah dengan volume darah secara keseluruhan yang dihitung dengan persentase. ${ }^{8}$ Berdasarkan penelitian lain pad tahun 1997 didapatkan hasil bahwa viskositas darah dapat dijadikan prediktor luaran pasien COT, karena aliran darah otak (ADO) akan menurun apabila viskositas darah meningkat. ${ }^{20}$ Oleh karena itu, peneliti mencoba melakukan penelitian sederhana untuk mengetahui hubungan antara hematokrit yang dapat memengaruhi viskositas darah dengan luaran pasien COT. Kadar hematokrit menurut penelitian yang sederhana ini belum dapat dipakai sebagai prediktor terhadap luaran pasien COT. Kadar hematokrit belum dapat dipastikan telah mengambil alih fungsi autoregulasi otak. Fungsi autoregulasi aliran darah otak akan hilang pada saat cedera kepala sehingga viskositas menjadi sangat penting dalam menentukan aliran darah otak dan menentukan viskositas darah. ${ }^{18}$

Hasil ini sejalan dengan penelitian lain pada tahun 2013 bahwa tidak terdapat peningkatan kadar hematokrit pada pasien COT. Hal ini kemungkinan disebabkan oleh beberapa faktor yang belum terdeteksi sebelum kejadian COT seperti keadaan status gizi atau adanya penyakit kronik yang dapat menurunkan kadar hematokrit. ${ }^{17}$ Penelitian ini hanya membuktikan ada tidaknya hubungan antara kadar gula darah dan hematokrit pada hari ke-0 dengan luaran pasien COT berdasarkan skor GCS hari ke-7. 
Penelitian sebelumnya telah dilakukan mengenai profil kadar gula darah dan hematokrit pada pasien COT, dan didapatkan hasil kadar gula darah meningkat sejalan dengan beratnya COT, sedangkan pada semua tingkatan COT, kadar hematokrit menurun. ${ }^{17}$ Penelitian lain di tahun 2016 menyatakan bahwa kadar gula darah dapat digunakan sebagai prediktor skor GCS pasien COT. Semakin tinggi kadar gula darah maka GCS pasien akan menurun. ${ }^{4}$ Selain itu, penelitian yang dilakukan pada tahun 2007 juga menyatakan bahwa terdapat hubungan yang kuat antara kadar gula darah dengan disability rating scale (DRS) pasien pada hari ke-14. Semakin tinggi kadar gula darah maka DRS pasien juga akan meningkat. ${ }^{16}$

\section{Simpulan}

Simpulan dari penelitian ini adalah terdapat hubungan yang bermakna antara kadar gula darah dengan luaran pasien COT, tetapi tidak terdapat hubungan antara hematokrit dengan luaran pasien COT berdasarkan skor GCS di RSUD Ulin Banjarmasin. Saran untuk penelitian ini adalah perlu dilakukan penelitian lanjutan dengan waktu penelitian yang lebih panjang dengan sampel yang lebih banyak serta dikelompokkan berdasarkan letak lesi dan terapinya. Selain itu juga perlu dilakukan penelitian lanjutan dengan variabel yang lain sebagai prediktor luaran pasien cedera otak traumatik.

\section{Daftar Pustaka}

1. Roozenbeek B, Maas AIR, Menon DK. Changing patterns in the epidemiology of traumatic brain injury. Nat Rev Neurol. 2013;9(4):231-36.

2. Badan Penelitian dan Pengembangan Kesehatan. Riset Kesehatan Dasar (RISKESDAS) 2013. Lap Nas 2013. 2013:1-384.

3. Shi J, Dong B, Mao Y, Guan W, Cao J, Zhu $\mathrm{R}$, et al. Review: Traumatic brain injury and hyperglycemia, a potentially modifiable risk factor. Oncotarget. 2016;7(43).
4. Rahmawati I. Kadar glukosa darah sebagai prediktor glasgow coma scale pasien cedera kepala. Instansi Ilmu Kesehatan Bhakti Wiyata Kediri. 2017;111-19.

5. Alvis-Miranda HR, Navas-Marrugo SZ, Velasquez-Loperena RA, Adie-Villafañe RJ, Velasquez-Loperena D, Castellar-Leones $\mathrm{SM}$, et al. Effects of glycemic level on outcome of patients with traumatic brain injury: a retrospective cohort study. Bull Emerg trauma. 2014;2(2):65-71.

6. Irawati L. Viskositas darah dan aspek medisnya. Majalah Kedokteran Andalas. 2017;34(2):102.

7. Zhou JK, Zhang QS, Chen YQ, Mu L, Xie Y, Ke JJ, et al. Use of hematocrit for short-term prognosis of patients with traumatic brain injury after decompressive craniectomy. World Neurosurg. 2018;14:1-6.

8. Deutsch H, Ullman JS. What is the optimal hematocrit and hemoglobin for head-injured patients?. In: Neurotrauma. 1st ed. New York: Thieme Medical Publisher; 2005. 88-90.

9. Sigalingging EY. Karakteristik cedera kepala di Rumah Sakit Umum Pusat Haji Adam Malik Medan. 2017:38-39.

10. Rawis ML, Lalenoh DC, Kumaat LT. Profil pasien cedera kepala sedang dan berat yang dirawat di ICU dan HCU. Jurnal e-Clinic. 2016;4(2).

11. Lin W, Yang L, Cai S, Zhu J, Feng Y, Yang $\mathrm{L}$, et al. Cognitive function and biomarkers after traumatic brain injury: protocol for a prospective inception cohort study. Asia Pac Clin Transl Nerv Syst Dis. 2016;1(4):170-76.

12. Eaton J, Hanif AB, Nsurg MS, Grudziak J, Charles A. Epidemiology, management, and functional outcomes of traumatic brain injury in sub-saharan africa. World Neurosurg. 2017. 
13. Kartinasari A. Hubungan skor GCS dengan fungsi kognitif pasien cedera otak traumatik di RSUD Ulin Banjarmasin. [Karya Tulis Ilmiah]. Univeritas Lambung Mangkurat Banjarmasin; 2018.

14. Algattas H, Huang JH. Traumatic brain injury pathophysiology and treatments: early, intermediate, and late phases post-injury. Int J Mol Sci. 2013;15(1):309-41.

15. Prasetyo RB. Hubungan skor GCS dengan kadar gula darah pasien cedera kepala di IGD RSUD Ulin banjarmasin. [Karya Tulis Ilmiah]. Universitas Lambung Mangkurat Banjarmasin; 2013.

16. Aritonang S. Hubungan kadar gula darah dengan outcome cedera otak traumatik tertutup derajat sedang-berat dengan gambaran brain ct-scan dalam batas normal. Universitas Diponegoro. 2007;1-15.
17. Komana. Profil kadar gula darah sewaktu dan hematokrit dan hasil akhir klinis penderita kontusio serebri pada tahun 2012 di IGD RSUP H. Adam Malik Medan. [Karya Tulis Ilmiah]. Universitas Sumatera Utara; 2013.

18. Obrist WD, Thomas W, Jaggi JL, Cruz J, Gennarelli TA. Cerebral blood flow and metabolism in comatose patients with acute head injury. J Neurosurg. 1984;61:241-53.

19. Hartoyo M, Raharjo SS, Budiyati. Prediktor mortalitas penderita cedera kepala berat di instalasi gawat darurat RSU Tugurejo Semarang. 2008;175-82.

20. Kelly DF, Martin NA, Kordestani R, Counelis G, Hovda DA, et al. Cerebral blood flow as a predictor of outcome following traumatic brain injury. J Neurosurg. 1997;86:633-41. 